\title{
Automatic Counting OF JeWELlery StoneS
}

\author{
KALOVA, I. \& HORAK, K.
}

Abstract: The aim of this project is an automatic determination of the number of glass cut stones in production batch. The designed system uses computer vision for this purpose and according to executed experiments achieves better results than classic, weighting used today. The stones are sprinkled on measuring area which is monitored by camera. The problems of detection of transparent objects (as well as clear stones) and overlaying of stones are solved by suitable scene preparation, choosing of light source and lighting methods and by means of exact way of image processing and evaluation.

Key words: camera, computer vision, image processing, lighting, transparency, stone
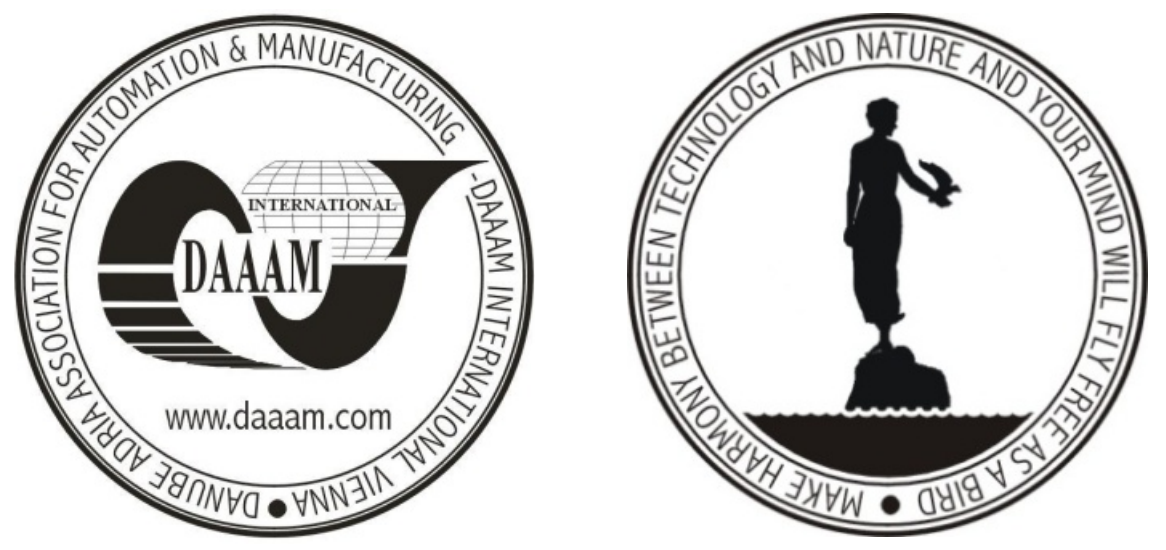

Authors' data: Ing. Ph.D. Kalova, I[lona]; Ing. Ph.D. Horak, K[arel], Brno University of Technology, Kolejní 2906/4, 61200, Brno, Czech Republic, kalova@feec.vutbr.cz,horakk@feec.vutbr.cz

This Publication has to be referred as: Kalova, I[lona] \& Horak, K[arel] (2009). Automatic Counting of Jewellery Stones, Chapter 43 in DAAAM International Scientific Book 2009, pp. 419-426, B. Katalinic (Ed.), Published by DAAAM International, ISBN 978-3-901509-69-8, ISSN 1726-9687, Vienna, Austria DOI: $10.2507 /$ daaam.scibook.2009.43 